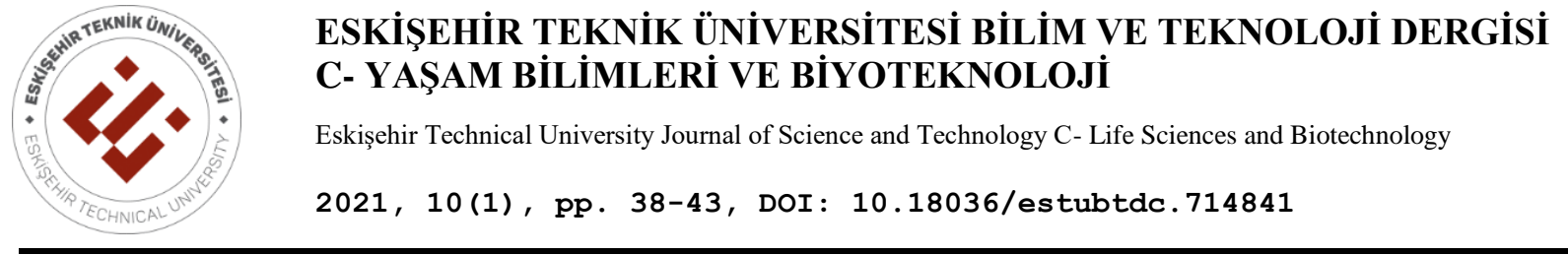

RESEARCH ARTICLE

\title{
THE PREVALENCE OF DICROCOELIIDAE (DIGENEA) LARVAL STAGES IN THE FIRST INTERMEDIATE HOST Helix lucorum, 1758 IN ESKISSEHİR AND BARTIN PROVINCES OF TURKEY
}

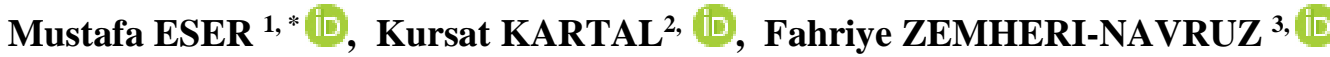 \\ ${ }^{1}$ Anadolu University Open Education Faculty Health Programs, Tepebasi, Eskişehir Turkey \\ ${ }^{2}$ Gazi Mustafa Kemal Anatolian High School, Biology Teacher, Tepebasi, Eskişehir, Turkey \\ ${ }^{3}$ Bartın University, Faculty of Science, Department of Molecular Biology and Genetics, Bartın, Turkey
}

\begin{abstract}
This study was conducted to determine the prevalence of Dicrocoeliidae larval stages in Helix lucorum found in Eskişehir and Bartın provinces of Turkey. Snails were collected from the pastures of Eskişehir and Bartın. The snails were anesthetised with $50 \mathrm{mM}$ sterilized magnesium chloride $\left(\mathrm{MgCl}_{2}\right)$ before dissected. Internal organs of the snail, specifically hepatopancreas, were analysed with a stereomicroscope for sporocyst and cercaria. The larval forms were identified and monitored with a light microscope. The prevalence of Dicrocoeliidae larval stages in Helix lucorum in Eskişehir and Bartın was found to be $4.6 \%$ and $7.0 \%$, respectively. Although cercariae in sporocysts were immature at the beginning of May, they began to grow and leave the sporocysts in the middle of May. It was understood that Helix lucorum served as an intermediate host to Dicrocoeliid trematodes in Eskişehir and Bartın provinces of Turkey.
\end{abstract}

Keywords: Dicrocoeliidae larval stage, Helix lucorum, Eskişehir, Bartın

\section{INTRODUCTION}

Dicrocoelium dendriticum (Digenea: Dicrocoeliidae) is known as small liver flukes. They live in bile ducts and gall bladders of the ruminants. Zoonotically, they can also cause infections in humans without showing any clinical symptoms [1,2]. Dicrocoeliasis causes a decrease in milk and meat yield $(2,3]$. Dicrocoeliasis is found to be wide in sheep $[4,5,6,7,8]$, goats $[5,7,9]$ cows $(10)$, equidae $[11,12]$, hares [13], and humans $[14,15,16,17,18]$. D. dendriticum is a trematode, which is $8-12 \mathrm{~mm}$ in length

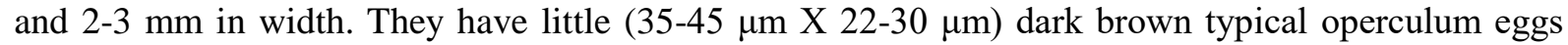
carrying miracidium $[12,3]$. D. dendriticum develop over two intermediate hosts. When the egg is eaten by a land snail, miracidium leaves the egg and penetrates into intestinal epithelium. Then, it moves to hepatopancreas. Within the primary sporocyst of hepatopancreas, female sporocysts occur after an asexual reproduction. These are named first-generation and second-generation sporocysts. Cercariae grow in the second-generation sporocysts and they move to respiration cells of the snail. Mucous including over 5,000 cercariae is disposed from these cells. Formica ants eat the mucous and the cercariae transform into metacercariae in the abdominal cavity of the ants. Some of these metacercariae are localized in sub-oesophageal ganglion of the ant. When the temperature drops below $15-20^{\circ} \mathrm{C}$, they cause cataleptic cramp. The paralyzed ants because of the cramp are eaten by final hosts and the hosts become infected with dicrocoeliasis. Metacercariae leave the cysts in the intestines of the final host and move up to bile ducts and gall bladder through ductus choledochus. Thereby they reach sexual maturity and their fertilized eggs are thrown away with feces. Cercariae in the first intermediate host (snails) occur in approximately 4 months and infected metacercariae in second intermediate hosts (ants) occur in 40 days [1, 3, 19]. Helix lucorum Linnaeus, 1758 live in moist pastures, orchards, and forests. In Turkey, they live widely in humid coastal areas. They are also exported as they are edible. Helix lucorumare seen

\footnotetext{
* Corresponding Author: meser961@anadolu.edu.tr

Received: 05.04.2020 Published: 25.01.2021
} 
in France, Iran and Caucasia [20]. This study was conducted to determine the prevalence of Dicrocoeliidae larval stages in Helix lucorum found in Eskişehir and Bartın provinces of Turkey.

\section{MATERIALS AND METHODS}

607 land snails that were collected from the provinces of Eskişehir (282) and Bartın (325) (H. lucorum) were used in the study. The snails were collected in May, 2016 and brought to the laboratory of Anadolu University Research Unit for Experimental Animals. $50 \mathrm{mM}$ sterilized magnesium chloride $\left(\mathrm{MgCl}_{2}\right)$ was used to dissect the snails. Internal organs and hepatopancreas of the snails were taken to the petri plates filled with physiological saline solution. The internal organs were cut into pieces and were analysed with a stereo microscope (Nikon SMZ800) whether they had larval forms in them. The samples including larval forms were viewed on a microscope (Nikon Eclipse 80i - DS-5M-L1 imaging system).

\section{RESULTS}

It was found that 13 land snails (4.6\%) out of 282 (Eskişehir); and 23 land snails (7.0\%) out of 325 (Bartın) had second generation sporocysts and cercariae. All of the larval developmental stages were collected from hepatopancreas. The sporocysts that were found at the beginning of May were first period second generation sporocysts and the cercariae in them had not had tails. In all of the second generation sporocysts, found in 36 snails in the middle of May, there were mature cercariae (Figure 1A), free cercariae (Figure 1B), and cercariae leaving the sporocyst (Figure 1C, 2D).

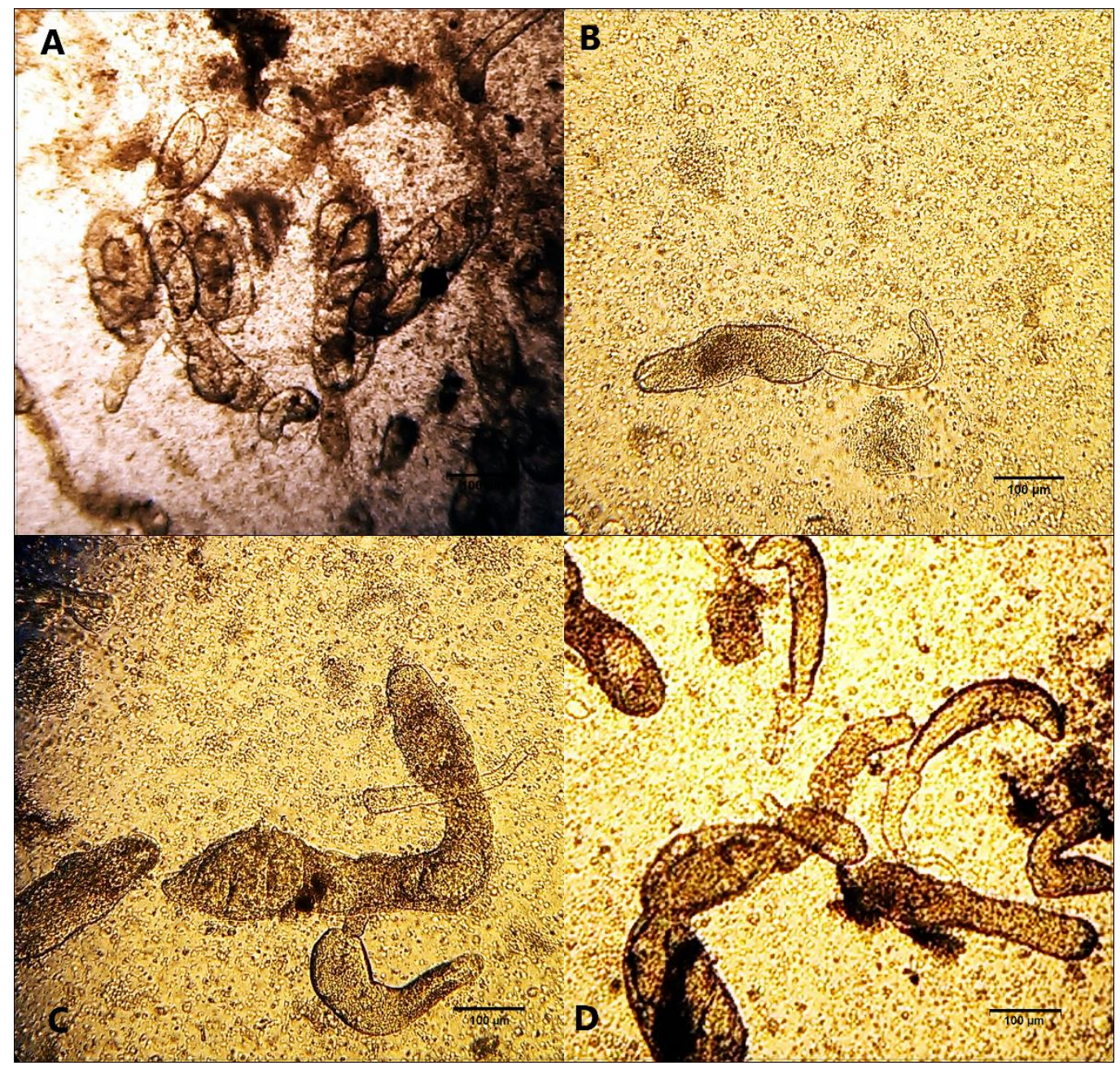

Figure 1. Cercaria inside sporocysts (A), free cercariae (B), cercariae is leaving from sporocysts (C, D) 


\section{DISCUSSION}

The reason why spring months were chosen to collect the snails is that snails hibernate. They become active in spring when the weather is warm and humid. That is, the possibility of getting parasite eggs with miracidium is high in spring. In this study, the prevalence of Dicrocoeliidae larval stages in Helix lucorum found in Eskişehir and Bartın provinces of Turkey was found to $4.6 \%$ and $7.0 \%$ respectively. It was reported for the first time that Helix aspersa was intermediate host to Dicrocoeliid in İzmir and the infection rate was $1.07 \%$ in May [21]. In a study conducted in Kastamonu, Dicrocoeliid larval forms were first reported in Helix lucorum in Turkey. The infection rate was 12.0\% in May [22]. In Mersin province the infection rate in Helix aspersa was found 2.4\% [23]. In Afyonkarahisar province the infection rate in Helix lucorum was reported 4.9\% [24]. In Van province the infection rate in Helix lucorum was reported 25.7\% [25]. The possibility for snails taking Dicrocoeliid eggs in Dicrocoeliosis epidemiology is bound to the activities of the snails. The type of snail, the age of snail, catchment basin of snail, infection dose, humidity, temperature and many other factors affect the development of larval forms [26].

Various snail species act as intermediate hosts to the larval forms of Dicrocoeliid. The different terrestrial snail species and Dicrocoeliid infection prevalence are shown in Table 1.

Table 1. Prevalence of infection with Dicrocoeliid larvae among different terrestrial snail species.

\begin{tabular}{lllllc}
\hline Country & Province & Year & Source & & Snail \\
& & & & Pelicella candicans & 4.3 \\
Turkey & Bursa & 1971 & 27 & Helicopsis derbentina & 4.0 \\
Turkey & Bursa & 1971 & 27 & Helicopsis krynickii & 2.6 \\
Turkey & Bursa & 1971 & 27 & Trochoidea pyramidata & 0.2 \\
Turkey & Bursa & 1971 & 27 & Monacha carthusiana & 2.8 \\
Turkey & Bursa & 1971 & 27 & Cernuella virgata & 1.0 \\
Turkey & Bursa & 1971 & 27 & Helicopsis protea & 0.8 \\
Turkey & Bursa & 1971 & 27 & Cochlicella acuta & 0.4 \\
Turkey & Bursa & 1971 & 27 & Helicella itala & 5.68 \\
Spanish & - & 1987 & 28 & Helicella obvia & 26.8 \\
Germany & - & 1993 & 29 & Helicella itala & 2.98 \\
Spanish & - & 2001 & 26 & Helicella corderoi & 1.06 \\
Spanish & - & 2001 & 26 & Helix aspersa & 0.97 \\
Turkey & İmir & 2007 & 21 & Helix lucorum & 27.6 \\
Turkey & Kastamonu & 2014 & 22 & Helix lucorum & 4.9 \\
Turkey & Afyonkarahisar & 2015 & 24 & Helix aspersa & 2.4 \\
Turkey & Mersin & 2015 & 23 & Chondrus tournefortianus & 2.27 \\
Turkey & Kastamonu & 2016 & 30 & Helix lucorum & 22 \\
Turkey & Van & 2017 & 25 & Xerolenta obvia & 0.78 \\
Turkey & Kastamonu & 2018 & 31 & Helix lucorum & 4.6 \\
Turkey & Eskişehir & 2016 & This study & Helix lucorum & 7.0 \\
Turkey & Bartin & 2016 & This study & & \\
\hline
\end{tabular}

In this study, it was seen that there were immature cercariae in sporocysts at the beginning of May and they grew mature and left the sporocysts in the middle of May. Towards the end of May, cercariae leaving the sporocysts in a mucous form became active and were taken by the second intermediate hosts, ants.

\section{CONCLUSION}

As a result, the prevalence of infection in intermediate host Helix lucorum in Eskişehir and Bartın provinces was identified. This study is thought to be an important source in controlling the infection. 
Eser et al. / Eskişehir Technical Univ. J. of Sci. and Tech. C-Life Sci. and Biotech. 10 (1) - 2021

\section{REFERENCES}

[1] Bürger HJ, Helminthen. In: Vererinärmedizinische Parasitologie. Boch J, Supperer R, 4. Auflage, Verlag Paul Parey, editors. Berlin und Hamburg, 1992. pp.174-319.

[2] Otranto D, Traversa D. A review of dicrocoeliosis of ruminants including recent advances in the diagnosis and treatment. Vet Parasitol. 2002; 107: 317-35.

[3] Otranto D, Traversa D. Dicrocoeliosis of ruminants: a little known fluke disease. Trends in Parasitol 2003; 19(1): 12-5.

[4] Gıcık Y, Arslan MÖ, Kara M, Akça A. Kars İlinde kesilen koyunlarda karaciğer kelebeklerinin yaygınlığı. Kafkas Üniv Vet Fak Derg 2002; 8(2): 101-2.

[5] Biçek K, Değer S. Tatvan Belediye mezbahasında kesilen koyun ve keçilerde karaciğer trematodlarının yaygınlığı. YYÜ Vet Fak Derg 2005; 16(1): 41-3.

[6] Sevimli F, Kozan E, Köse M, Eser M. Dışkı muayenesine göre Afyonkarahisar İli koyunlarında bulunan helmintlerin yayılışı. Ankara Üniv Vet Fak Derg 2006; 53: 13740.

[7] Çaya H. Adana İli mezbahalarında kesilen küçük ruminantlarda karaciğer helmint Enfeksiyonlarının şiddeti ve yayılışı. AVKAE Derg 2012; 2: 12-7.

[8] Karapınar A, Yıldırım A, Bişkin Z, Düzlü Ö, İnci A. Zara Yöresindeki koyunlarda fasciolosis'in koproantijen ELISA ve sedimentasyon-çinko sülfat flotasyon yöntemi ile araştırılması. Kafkas Üniv Vet Fak Derg 2012; 18(A): 7-12.

[9] Gül A, Aydın A. Hakkari (Yüksekova) Yöresinde kesilen kıl keçilerinde karaciğer kelebeklerinin yayılış1. T Parazitol Derg 2008; 32(4): 334-6.

[10] Sevimli F, Kozan E, Köse M, Doğan N. Afyon İli sığırlarında paramphistomosis ve distomatosisin genel durumu. T Parazitol Derg 2005; 29(1): 43-6.

[11] Umur Ş, Açıcı M. A survey on helminth infections of equines in the Central Black Sea region, Turkey. Turk J Vet Anim Sci 2009; 33(5): 373-8.

[12] Soykan E, Öge H. Türkiyenin farklı illerinde tek tırnaklılarda karaciğer trematodlarının yaygınlığı. T Parazitol Derg 2012; 36: 152-5.

[13] Gürler AT, Doğanay A. Ankara ve civarında bulunan tavşanlarda solunum ve sindirim sistemi helmintlerinin yaygınlığı. Ankara Üniv Vet Fak Derg 2007; 54: 105-9.

[14] Değerli S, Özçelik S, Çeliksöz A. The distribution of intestinal parasites in patients presenting at the parasitology laboratory of the Cumhuriyet University. Acta Parasitol Turcica 2005; 29: 116-9.

[15] Karadağ B, Bilici A, Döventaş A, Kantarc1 F, Selçuk D, Dinçer N, Öner YA. An unusual case of biliary obstruction caused by Dicrocoelium dentriticum. Scand J Infect Dis 2005; 37: $385-8$. 
[16] Çulha G. The distribution of patients with intestinal parasites presenting at the parasitology laboratory of the Mustafa Kemal University Medical Faculty. Acta Parasitol Turcica 2006; 30: 302-4.

[17] Soyer T, Turkmen F, Tatar N, Bozdogan O, Kul O, Yagmurlu A. Rare gallbladder parasitosis mimicking cholelithiasis: Dicrocoelium dendriticum. Eur J Pediatr Surg 2008; 18: $280-1$.

[18] Cengiz ZT, Yılmaz H, Dülger AC, Çiçek M. Human infection with Dicrocoelium dendriticum in Turkey. Ann Saudi Med 2010; 30(2): 159-61.

[19] González-Lanza C, Manga-González MY, Campo R, Del-Pozo MP. Larval development of Dicrocoelium dendriticum in Cernuella (Xeromagna) cespitum arigonis under controlled laboratory conditions. J Helminthol 1997; 71: 311-7.

[20] Yıldırım MZ, Kebapcı U, Gumuş BA. Edible snails (terrestrial) of Turkey. Turk J Zool 2004; 28: 329-35.

[21] Gürelli, Gözde; Göçmen, Bayram. Natural infection of Helix aspersa (Mollusca: Pulmonata) by Dicrocoeliidae (Digenea) larval stages in Izmir, Turkey. Infection 2007; 32(2): 150-153

[22] Gürelli, Gözde; Alay, Mehtap; Koymalı, Sevilay. Kastamonu civarında dağılış gösteren Helix lucorum Linnaeus, 1758 (Mollusca: Pulmonata)'da Dicrocoeliid (Trematoda: Digenea) larval safhalarının yaygınlığı. Turkiye Parazitol Derg 2014, 38(1): 37-40.

[23] Köse M, Eser M, Kartal K, Bozkurt MF. Infections of larval stages of Dicrocoelium dendriticum and Brachylaima sp. in brown garden snail, Helix aspersa, in Turkey. Korean J Parasitol 2015; 53: 647-651.

[24] Kartal K, Köse M, Eser M. The Prevalance of larval stages of small liver fluke Dicrocoelium dendriticum in the first intermediate host Helix lucorum Linnaeus, 1758 (Mollusca: Pulmonata) in Afyonkarahisar district. Kocatepe Vet J 2015; 8: 51-5.

[25] Ünlü, AH, Bilgiç, HB, Eren, H, Karagenç, T. Van İli civarında görülen Helix lucorum (Mollusca: Pulmonata)'da Dicrocoeliidae (Digenea) Larval Dönemlerinin Yaygınlığı. Türkiye Parazitol Derg 2017; 41: 204-207.

[26] Manga González MY, González-Lanza C, Cabanas E, Campo R. Contributions to and review of Dicrocoeliosis, with special reference to the intermediate host of Dicrocoelium dendriticum. Parasitol 2001; 123: 91-114.

[27] Kalkan A. Dicrocoelium dendriticum (Rudolphi, 1819), Looss, 1899 in Turkey I. Field studies of intermediate and final hosts in the South Marmara Region. British Veterinary Journal. 1971; 127: 67-75. 
Eser et al. / Eskişehir Technical Univ. J. of Sci. and Tech. C-Life Sci. and Biotech. 10 (1)-2021

[28] Manga-González M.Y. Some aspects of the biology and helminthofauna of Helicella (Helicella) itala (Linnaeus, 1758) (Mollusca). Natural infection by Dicrocoeliidae (Trematoda). Revista Ibérica de Parasitologia, Extraordinario. 1987; 131-148.

[29] Schuster R. Infection patterns in the first intermediate host of Dicrocoelium. Veterinary Parasitology. 1993; 47: 235-243.

[30] Gürelli G. Alay M. First record of the natural infection of Chondrus tournefortianus (Mollusca: Pulmonata) by Dicrocoeliidae (Digenea) larval stages in Kastamonu, Turkey. North-Western Journal of Zoology. 2016; 12: 188-191.

[31] Ismail FMAK, Gürelli G. Natural infection of the land snails Xerolenta obvia, Zebrina detrita, and Monacha samsunensis by Brachylaima sp. metacercariae in Kastamonu, Turkey. Turkish Journal of Zoology, 2018; 42(1), 152-157. 